\title{
Ileal and faecal protein digestibility measurement in humans and other non-ruminants - a comparative species view
}

\author{
Wouter H. Hendriks ${ }^{1,2 *}$, Jürgen van Baal $^{1}$ and Guido Bosch ${ }^{1}$ \\ ${ }^{1}$ Animal Nutrition Group, Wageningen University, PO Box 338, 6700 AH Wageningen, The Netherlands \\ ${ }^{2}$ Faculty of Veterinary Medicine, Utrecht University, PO Box 80.151, 3508 TD Utrecht, The Netherlands \\ (Submitted 29 April 2011 - Final revision received 29 July 2011 - Accepted 6 October 2011)
}

\begin{abstract}
A comparative non-ruminant species view of the contribution of the large intestinal metabolism to inaccuracies in nitrogen and amino acid absorption measurements is provided to assess potential implications for the determination of crude protein/amino acid digestibility in adult humans consuming lower digestible protein sources. Most of the amino acids in the hindgut are constituents of the microorganisms and significant microbial metabolism of dietary and endogenous amino acids occurs. Bacterial metabolism of nitrogen-containing compounds leads to a significant disappearance of nitrogen in the large intestine. Literature data show that some $79 \%$ of the nitrogen entering the large intestine of the horse is absorbed. For dogs, sows, and growing pigs these estimates are 49, 34 and 16\%, respectively. The coefficient of gut differentiation of humans compares closely to that of dogs while the coefficient of fermentation in humans is the lowest of all non-ruminant species and closest to that of cats and dogs. Large intestinal digesta transit times of humans compare closest to adult dogs. Significant amino acid metabolism has been shown to occur in the large intestine of the adult dog. Use of the growing pig as an animal model is likely to underestimate the fermentation of amino acids in the human large intestine. Based on the significant degree of fermentation of nitrogen-containing components in the large intestine of several non-ruminant species, it can be expected that determination of amino acid digestibility at a faecal level in humans consuming low quality proteins would not provide accurate estimates of the amino acids absorbed by the intestine.
\end{abstract}

Key words: protein: large intestine: fermentation: non-ruminant: review

\section{Introduction}

Protein is one of the dietary macronutrient groups and determination of the availability of individual dietary amino acids is a central concept in nutritional science and required for the formulation of nutritionally complete diets for humans and animals. Current feed evaluation systems and computerbased growth models for production animal species use the ileal digestibility of individual amino acids to predict the uptake of dietary amino acids, as the small intestine is considered the major site of amino acid absorption. In humans and companion animals such as cats, dogs, and horses, use of the ileal amino acid digestibility concept is less common for the routine evaluation of diets or dietary ingredients, although scientifically there have been many studies reporting ileal amino acid digestibility values in dogs. Due to technical, economical, and ethical constraints, apparent faecal nitrogen (N) digestibility values are used in companion animal nutrition to provide an indication of the adequacy of a diet to meet the animal's amino acid requirements ${ }^{(1,2)}$. In humans, similar constraints exist but measurements of ileal crude protein and amino acid digestibility of foods have been undertaken with ileostomates $^{(3,4)}$ or by using stable isotopes in conjunction with a naso-ileal intubation technique ${ }^{(5,6)}$. However, validated animal models appear more convenient and inexpensive for the evaluation of the ileal nutrient digestibility of human foods ${ }^{(7-10)}$.

The classic view of the function of the large intestine in humans and animals has been that of a structure providing a controllable route for the excretion of undigested feed, metabolic waste products and toxic substances, to conserve water and electrolytes, to contribute to overall energy supply, and to safely contain microorganisms present ${ }^{(11)}$. The large intestine's contribution to overall health, its relation to obesity, absorption of water-soluble vitamins synthesized by the microbiota, and diversity and functionality of its microbial community in both humans and animals is increasingly being recognised $^{(12-15)}$. The microbiota resident in the large intestine, moreover, can have a profound effect on the determination of the digestibility of crude protein and amino acids. It has been estimated that $50-80 \%$ of the faecal $\mathrm{N}$ in pigs is part of the microbiota $^{(16,17)}$, while in humans $60 \%$ of the total faecal $\mathrm{N}$ appears to be contained in bacteria $^{(18)}$. As such, faecal amino acid excretion is largely indicative of microbial $\mathrm{N}$ metabolism which in turn is dependent on a number of factors

*Corresponding author: W. H. Hendriks, fax +31 3174842 60, email wouter.hendriks@wur.nl 
including dietary and endogenous nutrient inflow from the ileum, urea inflow from the large intestine, extent of microbial activity, species specific intestinal morphology and physiology, and digesta transit time.

This review provides a comparative non-ruminant animal species view of the contribution of the large intestine to potential inaccuracies in faecal $\mathrm{N}$ and amino acid absorption measurement in order to assess potential implications for the determination of crude protein/amino acid digestibility in adult humans, especially when lower digestible protein sources are consumed. Although the present review of the differences between non-ruminant animal species in the physiology of the large intestine is not intended to be exhaustive, the examples presented here do illustrate clear differences between animals that may be used as models in human nutrition research.

\section{Evidence for large intestinal amino acid and peptide carriers in the large intestine of various species}

It has been shown that larger, more complex molecules such as thiamine, folate, biotin, riboflavin, and pantothenic acid are actively absorbed across the large intestine wall and make a significant contribution to vitamin homeostasis of humans and animals ${ }^{(13)}$. Molecular techniques have been developed and improved over the last decade and used to determine the existence of amino acid transport systems in the caecum and colon of a number of non-ruminant species. These techniques provide novel insights to the amino acid and peptide uptake capacity of the large intestine. Reverse transcription polymerase chain reaction (RT-PCR) demonstrated that L-amino acid transporter 1 (LAT1) which conveys the transport of large branched and neutral aromatic amino acids, is expressed along the whole mouse intestine, including the caecum ${ }^{(19)}$. LAT2 expression was not found in the human colon but occurred weakly in mouse colon ${ }^{(20)}$. Western blot analysis on freshly isolated rat intestinal cells demonstrated that LAT1 and LAT2 are intensively expressed in both the small and large intestine. Expression of LAT1 in the colon was 2 -fold that in the jejunum and 3 -fold that in the ileum $^{(21)}$. Recently, it has been demonstrated by RT-PCR that the mRNA abundance of LAT3 is almost similar or greater in the caecum and colon respectively of the equine intestinal tract compared with the small intestine, suggesting that the large intestine might contribute to both cationic and neutral amino acid uptake and absorption ${ }^{(22)}$. Immunohistochemistry has demonstrated that in the human colon glycine transporter 1 (GLYT1; SLC6A9) protein is localised to the membrane of cells lining the crypts with strong staining at both apical and basal surfaces ${ }^{(23)}$. In humans, excitatory amino acid carrier 1 (EAAC1) has been found to be abundantly expressed in the colon as well as the small intestine. RT-PCR analysis demonstrated that solute carrier family 6 (amino acid transporter) member 14 (SLC6A14, ATB0 + ) is expressed throughout the whole colon in humans, with the highest level in the descending segment ${ }^{(24)}$. Northern blot analysis showed a similar distribution of SCL6A14 in the intestinal tract of the black bear, with high levels in the distal region compared to the proximal part of the intestine ${ }^{(25)}$. Strikingly, SLC6A14 showed an apparent affinity for several D-amino acids ${ }^{(26)}$. Its colonic expression may have relevance for the absorption of bacterially derived D-amino acids as D-serine is transported by SLC6A14 ${ }^{(19)}$. Alternatively, as SLC6A14 is also able to transport carnitine, it is possible that SLC6A14 plays a role in the colonic absorption of carnitine and in this way competes with colonic bacteria for carnitine in the lumen ${ }^{(27)}$. Two members of the high-affinity glutamate transporter family have been described: ASC transporter 1 (ASCT1) and ASCT2 ${ }^{(28)}$. In addition, to alanine, serine, and cysteine, ASCT1 and ASCT2 also transport glutamate with low affinity at neutral $\mathrm{pH}$ and with increased affinity at reduced $\mathrm{pH}$. ASCT2 appears to be located in the apical membrane, and in the rabbit there is a gradient along the small and large intestine; i.e. ASCT2 expression is lowest in the duodenum and highest in caecum and colon ${ }^{(29)}$. However, because of its antiporter system, it is questionable whether ASCT2 could contribute to net transport of neutral amino acids across the apical membrane ${ }^{(30)}$. Proton-dependent amino acid transporter 1 (PAT1) is a $\mathrm{pH}$-dependent, low-affinity, high-capacity transporter for both taurine and $\beta$-alanine ${ }^{(24)}$, and PAT1 mRNA has been detected in human small intestine and ascending colon ${ }^{(31)}$. Immunostaining demonstrated an apical localization of PAT1 in rat and human small intestine ${ }^{(31)}$. Mouse PAT1 shows the highest expression in the small intestine and colon, whereas PAT2 was hardly detectable ${ }^{(32)}$. In humans, expression of PAT1 mRNA was detected throughout the whole length of the intestine, from duodenum to descending colon ${ }^{(24)}$. Besides amino acid transport, PAT1 and PAT2 expression in oocytes revealed that these proton amino acid transporters can transport short-chain fatty acids. PAT1 is most likely the low-affinity transporter of taurine in the luminal membrane of human enterocytes $^{(24)}$. Another intestinal carrier that mediates taurine and beta-alanine transport across the apical brush-border of the intestine is the taurine transporter (TauT, SLC6A6). This transporter is expressed along the entire human intestinal tract, including the ascending, transverse, and descending colon as determined by RT-PCR ${ }^{(24)}$. The transporter also has weak affinity for neutral amino acids such as phenylalanine. It has been shown by RT-PCR that in the rat proline transporter (SIT1, SLC6A20) expression was significant in the small intestine with lesser expression in the caecum and colon ${ }^{(33)}$. The distribution of peptide transporter 1 (PEPT1) expression in the intestinal tract is controversial. In most studies, PEPT1 mRNA was not observed in the colon of rats ${ }^{(34)}$, pigs ${ }^{(35)}$, dairy cows ${ }^{(35)}$, or healthy humans ${ }^{(36)}$. However, others reported a weaker but still significant mRNA expression of PEPT1 in human colon, compared with the small intestine ${ }^{(37)}$. PEPT1 mRNA was detected in human colon at approximately fivefold lower levels than found in the ileum ${ }^{(38,39)}$. Western blot analysis on various intestinal segments of the rat revealed positive staining for PEPT1 in the small intestine, with the strongest staining in jejunum, whereas no signal was detectable in the colon ${ }^{(38)}$. PEPT2 expression was detected by RT-PCR equally in the small and large intestine of human and rhesus monkey ${ }^{(38)}$.

Although amino acid transport systems are present in the large intestine of humans and a number of animal species, 
substrate availability may be limited. The caecal and colonic microbiota reside in an anaerobic environment and a significant number are amino acid fermenting species $^{(40,41)}$. Undigested and endogenous proteins, peptides, and amino acids can be metabolised by these species in the large intestine by the action of proteases, peptidases, and amino acid deaminases and decarboxylases yielding a large number of luminal metabolites including ammonia) $\left(\mathrm{NH}_{3}\right)$, short-chain fatty acids, branched-chain fatty acids, phenols, indols, amines, hydrogen, carbon dioxide, and methane ${ }^{(40,42)}$. The proximal and distal colon content in humans can contain free amino acids in millimolar amounts with hydroxyproline, alanine, lysine, and valine being most prominently available. Free amino acid concentrations increase distally for a number of the amino acids including lysine, alanine, valine, and glutamine. Also relatively large quantities of soluble protein and peptides can be present in the luminal content throughout the large intestine ${ }^{(43)}$. In rabbits, the caecum, upper colon and lower colon also contain millimolar amounts of free amino acids with glutamic acid, alanine, aspartic acid, glycine, and lysine being most abundant ${ }^{(44)}$. Based on these studies it appears that free amino acids, either of dietary, endogenous, or bacterial origin are present in the digesta of the large intestine and could potentially be absorbed by transported systems present in this part of the gastrointestinal tract. Evidence suggests that the substrate preference of intestinal bacteria are $\mathrm{NH}_{3}$ and peptides rather than amino acids ${ }^{(43)}$ making peptide transport less likely.

Several in vivo and in vitro studies have been designed to determine the absorption of amino acids from the large intestine in a number of species including humans, pigs, poultry, horses, and dogs. Two of the species where large intestinal amino acid absorption might be expected to contribute significantly to overall amino acid supply due to their copious large intestine are horses and rabbits, although rabbits perform coprophagia enabling utilisation of bacterial synthesised amino acids. Slade et al. ${ }^{(45)}$ injected a ${ }^{15} \mathrm{~N}$ labelled cell suspension into the caecum of a horse and found labelled dietary essential and non-essential amino acids in serum from the caecal vein. As most amino acids can be labeled through transamination, the latter however cannot be considered direct evidence for the absorption of intact amino acids from the large intestine. Infusion of $75 \mathrm{~g}$ of lysine in the caecum of horses did not result in increases in plasma lysine ${ }^{(46)}$ indicating that there is no significant absorption of lysine from the large intestine of the horse. Recently, Woodward et al. ${ }^{(22)}$ reported the presence of cationic and neutral amino acid transporter transcripts in the caecum, left ventral and dorsal colon that could facilitate the transport of amino acids across the large intestine. Furthermore, significant reflux of caecal content into the ileum is possible in horses. Unlike humans and dogs where most of the propagated ileocolonic sphincter contractions originate from the ileum, in horses approximately two-thirds originate from the extended caecum which is followed by a decrease in ileal $\mathrm{pH}$ indicative of reflux of caecal content ${ }^{(47)}$, thereby providing a potential means of absorbing dietary and microbial peptides and amino acids. The topic of peptide and amino acid absorption from the large intestine of horses however remains controversial ${ }^{(48)}$ In birds, amino acid absorption from the caeca is possible ${ }^{(49,50)}$ and may potentially contribute to overall amino acid supply. Although the proximal colon of the 3-day-old pig has been reported to be able to absorb amino acids ${ }^{(51)}$, this ability appears to be lost with increasing age. Infusing free amino acids into the caecum and colon of horses ${ }^{(46)}$ and pigs ${ }^{(52)}$ has not shown significant amino acid absorption in vivo. However the possibility of reflux of caecal contents might be a means of absorbing microbially synthesised and unabsorbed dietary and endogenous amino acids and peptides. Infusing the caecum of a pig with ${ }^{15} \mathrm{~N}$ labelled amino acids from a bacterial cell suspension ${ }^{(53)}$ has been reported to result in the appearance of labelled free amino acids in the venous blood of the colon.

It is the current consensus that although some absorption of amino acids may occur, the large intestine does not contribute significantly to the amino acid supply of pigs, humans, dogs, and horses ${ }^{(10,54,55)}$. In chickens and other birds however, there may be significant absorption of amino acids, although confirmatory evidence is needed. Recently developed molecular techniques have provided new insights into the amino acid and peptide uptake potential of the large intestine with a greater focus towards specific carrier systems than before, allowing a more targeted evaluation of the importance of the large intestine to overall amino acid supply in non-ruminant animals

\section{Apparent ileal and faecal $\mathrm{N}$ and amino acid digestibility values in various species}

As there appears to be no significant absorption of amino acids from the large intestine of non-ruminant species, observed hindgut $\mathrm{N}$ disappearance in ileal and faecal $\mathrm{N}$ digestibility studies are the predominant result of absorption of $\mathrm{NH}_{3}$ liberated from amino acid catabolism by microbial deaminases. Few studies have reported the difference between apparent ileal and faecal digestibility of $\mathrm{N}$ and amino acids in human subjects by direct comparison. Data from Gibson et al. ${ }^{(3)}$ show that differences between faecal and ileal $\mathrm{N}$ digestibility as measured in normal subjects or subjects with an ileostomy or ileo-rectal anastomosis consuming a low ( $40 \mathrm{~g} / \mathrm{d})$ and high $(100 \mathrm{~g} / \mathrm{d})$ crude protein diet were $9 \cdot 4$ and $6.4 \%$, respectively. The difference in apparent ileal and faecal $\mathrm{N}$ digestibility of a meat, vegetable, fruit, bread, and dairy product based diet between ileostomates and subjects with a functioning large intestine was reported to not differ statistically (86.9 vs. $88.9 \%)^{(4)}$. However statistically significantly higher apparent faecal amino acid digestibility values were reported for arginine (2.4\%), aspartic acid (2.4\%), serine (5.4\%), threonine (4.4\%), proline $(4.7 \%)$, glycine $(15.0 \%)$, phenylalanine $(1.7 \%)$, and tryptophan $(5.9 \%)$. A significantly lower value (ileal $<$ faecal) was reported for methionine (9.8\%). Recently, using the nasointestinal intubation technique, the difference in true ileal and faecal $\mathrm{N}$ digestibility of subjects consuming ${ }^{15} \mathrm{~N}$ labelled milk was found to be not statistically significant $(95.5 \mathrm{vs} .96 \cdot 6 \%)^{(5)}$ These data indicate that although differences in site of sampling have been observed to be significant, differences in humans appear to be small for $\mathrm{N}$ and only certain amino acids show 
statistically significant differences. These studies however have all used relatively highly digestible diets. In general, the lower the ileal protein and amino acid digestibility, the larger the potential error when measuring faecal amino acid or $\mathrm{N}$ digestibility.

To determine the magnitude of the inaccuracy in apparent faecal $\mathrm{N}$ digestibility (i.e. the faecal-ileal digestibility differences) with decreasing protein digestibility, so as to allow extrapolation to humans, a literature review was conducted. Data were obtained from peer reviewed publications reporting apparent ileal and faecal $\mathrm{N}$ digestibility in the same diet for a number of animal species including horses, rabbits, rats, pigs, dogs, blue foxes, and chickens. Besides $\mathrm{N}$ digestibility data, information was collected for daily dietary $\mathrm{N}$ intake and the body weights of the animals. Table 1 gives an overview of the differences observed in these studies between apparent ileal and faecal $\mathrm{N}$ digestibility. The largest number of studies was found for growing pigs followed by adult dogs. No studies were found for cats, guinea pigs or mice. Figure 1 shows the data for pigs and adult dogs (panel A) and horses, rabbits, and rats (panel B) and the linear regression line for each species. In all species apparent faecal $\mathrm{N}$ digestibility was generally higher than the corresponding ileal digestibility values and the differences between apparent ileal and faecal $\mathrm{N}$ digestibility decreased with increasing apparent ileal digestibility. For sows, horses, and rats, the slope of the linear regression line was the lowest $(0 \cdot 137,0 \cdot 318$, and 0.342 , respectively) followed by the dog ( 0.491$)$ and growing pig (0.710). A more extensive deviation from a slope of 1.0 indicates a lesser concordance between apparent ileal and faecal $\mathrm{N}$ digestibility. Diet composition can be considered one of the major determinants of this lack of concordance. This is shown by the within-study variation in the difference between apparent ileal and faecal $\mathrm{N}$ digestibility for different protein sources (e.g. $7 \cdot 0$ and $15 \cdot 6 \%$ in dogs ${ }^{(56)}$ and 3 to $19 \%$ in growing pigs ${ }^{(57)}$ ) or when fermentable fibres are supplied stimulating microbial protein synthesis (e.g. $10 \cdot 8$ to $30 \cdot 4 \%$ in $\operatorname{dogs}^{(58)}$ ). The relationship for young and growing pigs was less clear, partly due to the absence of accurate information on the body weight of the animals and some of the experimental dietary treatments in the dataset. The average (minimal and maximal) apparent large intestinal $\mathrm{N}$ digestibility was $65.8 \%$ for horses ( 42.0 to $80 \cdot 5 \%), 33.7 \%$ for dogs $(-19 \cdot 9$ to $70 \cdot 2 \%)$, $34.6 \%$ for sows ( $17 \cdot 1$ to $59 \cdot 3 \%)$, and $30.5 \%$ for growing pigs ( -24.6 to 89.3\%) (data not shown). Overall, these data show a significant disappearance of $\mathrm{N}$ from the large intestine for a number of non-ruminant species. Notable is the small disappearance of $\mathrm{N}$ from the large intestine of chickens and blue foxes (Table 1). For the latter species however, the dataset was limited to relatively highly digestible diets (81-86\%) as for humans.

The large quantity of $\mathrm{N}$ disappearing from the large intestine is likely a direct result of the deamination of amino acids (dietary or endogenous) or catabolism of other $\mathrm{N}$-containing compounds such as urea to $\mathrm{NH}_{3}$ by the microbiota, with subsequent diffusion of $\mathrm{NH}_{3}$ across the intestinal wall and excretion in the urine ${ }^{(10,54,59,60)}$. Figure 2 presents the daily apparent dietary $\mathrm{N}$ uptake per unit metabolic body weight $\left(\mathrm{BW}^{0.75}, \mathrm{MBW}\right)$ in relation to the daily apparent dietary large intestinal $\mathrm{N}$ inflow for horses, dogs, and sows. The extent of $\mathrm{N}$ disappearance in the large intestine is represented by the slope(s) of the regression lines, and indicates that the largest amount of protein per unit MBW is fermented in horses, followed by dogs, and then pigs. For the horse, apparent dietary $\mathrm{N}$ disappearance from the large intestine was approximately $79 \%$ of the apparent dietary $\mathrm{N}$ entering from the ileum. In adult dogs, $46 \%$ disappears in the large intestine while $34 \%$ disappears from sows. The position of the dog in this sequence may be somewhat surprising as dogs are adaptive carnivores. Urea is entering the gut in all gut segments but it is most effectively recycled in the hindgut where a transepethilial concentration is maintained by ureolytic bacteria ${ }^{(59)}$. Urea recycling reduces the magnitude of the dietary $\mathrm{N}$ disappearance from the hindgut and underestimates the magnitude of hindgut amino acid catabolism if ileal and faecal digestibility values are used.

\section{To which animal species can human large intestinal fermentation be best compared?}

The growing pig is often supported as a model animal for digestion studies in adult humans ${ }^{(10,54)}$ although they are fed

Table 1. Overview of ileal apparent $\mathrm{N}$ digestibility data and the difference between ileal and faecal apparent dietary $\mathrm{N}$ digestibility according to animal species

\begin{tabular}{|c|c|c|c|c|c|c|c|c|c|c|c|c|}
\hline \multirow[b]{2}{*}{ Species } & \multirow[b]{2}{*}{ No. of studies } & \multirow[b]{2}{*}{ No. of obs. } & \multicolumn{5}{|c|}{ Ileal apparent dietary $\mathrm{N}$ digestibility (\%) } & \multicolumn{5}{|c|}{$\begin{array}{l}\text { Difference in ileal and faecal apparent dietary } \\
\qquad \mathrm{N} \text { digestibility }(\%)^{\star}\end{array}$} \\
\hline & & & Min & Max & Median & Mean & SD & Min & Max & Median & Mean & SD \\
\hline Rat & 2 & 10 & $64 \cdot 1$ & $89 \cdot 7$ & $83 \cdot 3$ & $81 \cdot 2$ & 7.5 & $-6 \cdot 1$ & $14 \cdot 9$ & 3.9 & $5 \cdot 2$ & $6 \cdot 5$ \\
\hline Rabbit & 1 & 3 & $57 \cdot 0$ & 66.5 & $62 \cdot 4$ & $62 \cdot 0$ & $4 \cdot 8$ & $12 \cdot 0$ & $14 \cdot 2$ & $13 \cdot 9$ & $13 \cdot 4$ & $1 \cdot 2$ \\
\hline Horse & 4 & 15 & $1 \cdot 3$ & $70 \cdot 5$ & $45 \cdot 8$ & $41 \cdot 3$ & $19 \cdot 0$ & $2 \cdot 3$ & $64 \cdot 8$ & $39 \cdot 2$ & $38 \cdot 0$ & $15 \cdot 5$ \\
\hline Pig & 48 & 263 & $42 \cdot 2$ & $92 \cdot 0$ & 74.0 & 73.4 & 8.9 & $-4 \cdot 7$ & $24 \cdot 9$ & $8 \cdot 0$ & $8 \cdot 3$ & $5 \cdot 0$ \\
\hline growing & 46 & 247 & $42 \cdot 2$ & $92 \cdot 0$ & $74 \cdot 2$ & $73 \cdot 8$ & $8 \cdot 8$ & $-4 \cdot 7$ & $24 \cdot 9$ & $8 \cdot 0$ & $8 \cdot 1$ & $5 \cdot 0$ \\
\hline sow & 2 & 16 & $52 \cdot 2$ & 80.5 & $68 \cdot 5$ & $66 \cdot 9$ & $7 \cdot 6$ & $6 \cdot 1$ & $18 \cdot 6$ & $11 \cdot 2$ & 11.1 & $4 \cdot 1$ \\
\hline Dog & 30 & 141 & $51 \cdot 1$ & 90.5 & 73.4 & 73.5 & 8.5 & $-4 \cdot 1$ & $31 \cdot 3$ & 8.9 & $9 \cdot 4$ & $6 \cdot 0$ \\
\hline Blue fox & 1 & 4 & $81 \cdot 0$ & 86.4 & $84 \cdot 1$ & 83.9 & 2.5 & -0.1 & 1.5 & 0.3 & 0.5 & 0.7 \\
\hline Chicken & 3 & 23 & $56 \cdot 0$ & $86 \cdot 0$ & $81 \cdot 0$ & $76 \cdot 7$ & 9.5 & -13.0 & $16 \cdot 0$ & $-1 \cdot 0$ & 0.7 & $6 \cdot 6$ \\
\hline Human & 2 & 3 & $71 \cdot 7$ & 86.9 & 83.5 & $80 \cdot 7$ & 8.0 & $2 \cdot 0$ & 9.4 & $6 \cdot 4$ & $5 \cdot 9$ & 3.7 \\
\hline
\end{tabular}

* (faecal apparent dietary $\mathrm{N}$ digestibility - ileal apparent dietary $\mathrm{N}$ digestibility $) \times 100$. 

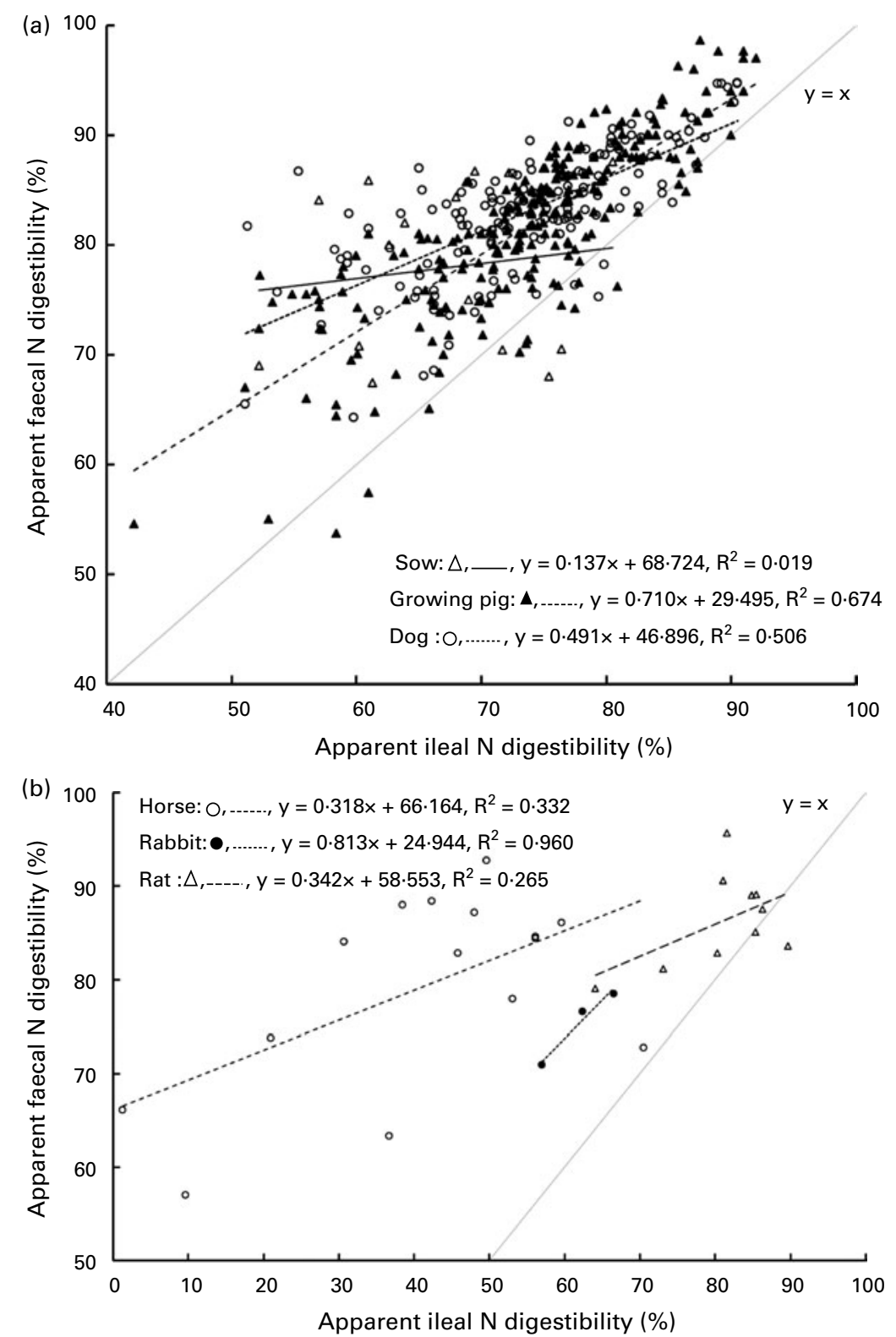

Fig. 1. (a) lleal vs. faecal apparent $\mathrm{N}$ digestibility data for sows, growing pigs, and dogs with trend lines. (b) lleal vs. faecal apparent $\mathrm{N}$ digestibility data for horses, rats, and rabbits with trend lines.

well above their maintenance requirements unlike adult humans who have an energy intake around maintenance. The digestion/fermentation of amino acids in the large intestine (caecum and colon) of non-ruminants is affected by digesta transit time. The extent of fermentation occurring in the caecum and colon of non-ruminants will also depend on the differentiation that these two structures have undergone throughout evolution. Quantitative morphometric data of the intestinal tract of a number of laboratory animals (mice, rats, and guinea pigs), companion animals (cats, dogs, and horses), production animals (pigs) and humans based on planimetry of the entire digestive tract combined with assessment of surface area enlargement due to microscopically important structural entities such as visible villi, crypts, mounds, plicaecirculares, "opened crypts" in caecum or colon have been reported $^{(61,62)}$. Not included is the surface enlargement due to microvilli which increases gut surface area significantly. Snipes ${ }^{(63)}$ estimated that the surface enlargement factors due to microvilli in the caecum and the colon of the giant pouch rat are 15 and 19-20 fold while in the duodenum, jejunum and ileum factors of 21, 26 and 24 were reported. Although this morphometric information is important to determine total surface area, villous atrophy is known to occur due to changes in nutrient supply, bioactive dietary components, luminal microbiota, toxins, and disease $\mathrm{e}^{(64-67)}$. Small intestinal surface area has been reported to scale closely to isometry with respect to MBW in the above-mentioned non-ruminant species. Although colonic surface area scales isometrically to MBW, the goodness of fit is much lower compared to that of the small intestine. Caecum surface area shows a large 


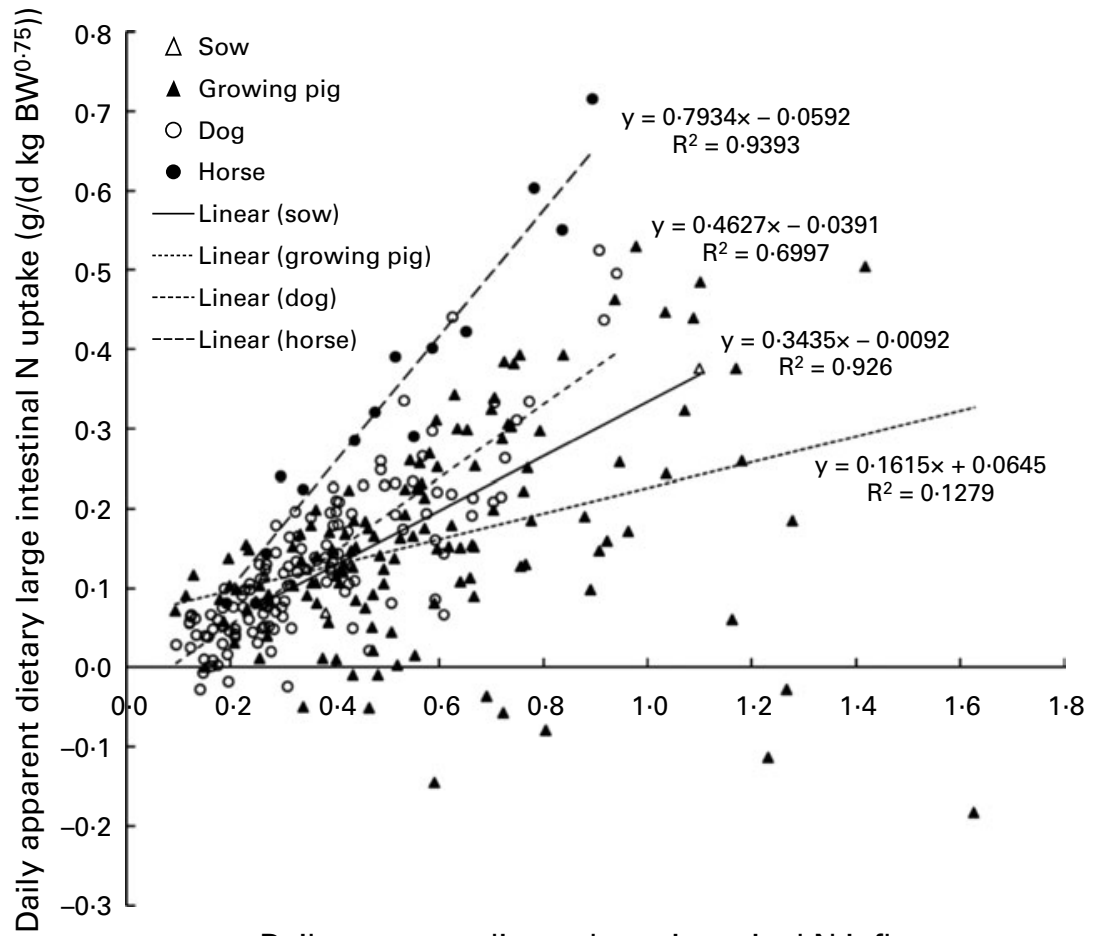

\section{Daily apparent dietary large intestinal $\mathrm{N}$ inflow} $\left(\mathrm{g} /\left(\mathrm{d} \mathrm{kg} \mathrm{BW} \mathrm{W}^{0.75}\right)\right)$

Fig. 2. Daily apparent dietary large intestinal $\mathrm{N}$ uptake per unit metabolic body weight in relation to the daily apparent dietary large intestinal $\mathrm{N}$ inflow for sows, growing pigs, dogs, and horses.

variation and is allometrically scaled to MBW. With respect to intestinal volume, all three compartments are allometrically scaled to MBW. Morphometrics of the human large intestine are presented in Fig. 3 in terms of surface area and volume where two isometric lines are drawn for comparison of humans to other species. Relative volume of the human large intestine compares closely to dogs, rats, and mice while relative surface area compares favourably to dogs and cats. Pigs have both a higher relative volume and surface area of the large intestine compared to humans. The coefficient of gut differentiation (area large intestine/area small intestine $\times 100$ ),

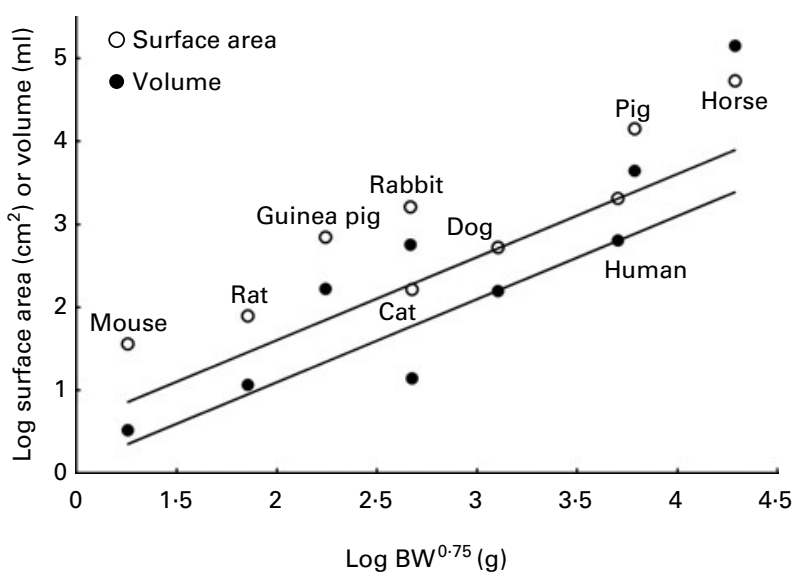

Fig. 3. Surface area and volume of the large intestine for various nonruminant species and comparison of the isometric relationship relative to humans (lines). an indicator of the importance of the functional participation of the large intestine in the absorptive process ${ }^{(68)}$, shows values for humans of 7 , cats 9 , dogs 11 , rats 30 , mice 31 , pigs 41 , horses 51 , guinea pigs 72 , and rabbits 103 . Similarly, the coefficient of fermentation (large intestinal/small intestinal volume $\times 10$ ), an indicator of the participation of the large intestine in the fermentation processes, is for humans only $0 \cdot 7$, cats $2 \cdot 9, \operatorname{dog} 4 \cdot 1$, rats $10 \cdot 2$, mice $7 \cdot 2$, pigs $9 \cdot 9$, horses $29 \cdot 8$, guinea pigs $31 \cdot 7$, and rabbits $71 \cdot 2$. These data indicate that the large intestine of the dog would be the closest match to humans when it comes to large intestinal morphology. The rat and pig, often used to study nutritional aspects of humans ${ }^{(8,10,54)}$ compare less favourably but better than other non-ruminants. Such observations, however, do not invalidate the pig as a model for human upper tract digestion.

Besides comparative quantitative morphometric data, transit time of food/digesta affects large intestinal amino acid degradation by the microbiota and $\mathrm{NH}_{3}$ diffusion across the large intestinal wall. The importance of large intestinal transit time on nutrient fermentation by the microbiota was investigated by feeding a mixed diet to the energy requirements of 7 human subjects and changing the mean transit time by administration of drugs affecting colonic motility ${ }^{(69)}$. Drug doses were adjusted to halve or double the mean transit time compared to a control group. Decreasing mean colonic transit time by $54 \%$ resulted in an increased stool weight and significant increase in bacterial mass from 16.5 to $20.3 \mathrm{~g}$ /day. Increasing mean transit time to $186 \%$, decreased stool 
weight, and decreased bacterial mass from a mean of 18.9 to $16 \cdot 1 \mathrm{~g}$ /day. Bacterial mass and transit time were significantly correlated indicating that changes in transit time alter microbial growth which in turn affects the quantity of $\mathrm{N}$ fixed as microbial protein and $\mathrm{NH}_{3}$ generated.

In general, the total gastrointestinal transit time largely reflects the transit time through the large intestine in nonruminant animal species. Specific data of transit time through the large intestine and its segments (i.e. caecum, colon) are however limited. Data on large intestinal transit time for several non-ruminant animal species are shown in Table 2. In healthy adult humans, large intestinal transit time of digesta varied considerable within studies ranging from 9 to $46 \mathrm{~h}^{(70)}$, 21 to $76 \mathrm{~h}^{(71)}$, and 14 to $75 \mathrm{~h}^{(72)}$. This inter-individual variation indicates that regulation of the digesta transit by the large intestine is complex and may depend on various factors (e.g. food type, gender, age, physical activity). The average large intestinal transit time in these studies was found to be $28 \mathrm{~h}^{(70)}, 43 \cdot 5 \mathrm{~h}^{(71)}$, and $39 \cdot 0 \mathrm{~h}^{(72)}$. With a length of the large intestine of approximately 100 to $150 \mathrm{~cm}^{(73)}$, the rate of transit would be 2.3 to $5.4 \mathrm{~cm} / \mathrm{h}$. The transit time through the total large intestine in rats is within the lower range of that observed in humans and is affected by age ${ }^{(74,75)}$ and diet $^{(76,77)}$. The large intestinal transit time increased with age in rats from $18 \cdot 1 \mathrm{~h}$ at 19 days of age to $37.4 \mathrm{~h}$ at 561 days of age ${ }^{(74,75)}$. In rats, the site of digesta retention within the large intestine varies considerably, with caecal digesta retention accounting for $42 \%^{(74,78)}, 12 \cdot 2$ to $29 \cdot 2 \%^{(74,75)}$, 69 to $84 \%\left({ }^{(76)}\right.$, and 41 to $75 \%{ }^{(77)}$ of the total transit time. Caecal digesta residence time is, at least in part, related to the amount of dietary fermentable substrate. Rats showed longer caecal digesta residence with increasing amounts of dietary raw potato $\operatorname{starch}^{(77)}$. The rate of transit through the colon ranged from 1.3 to $1.6 \mathrm{~cm} / \mathrm{h}^{(77)}$. In rabbits, there is a considerable difference in digesta transit time through the large intestine between liquid phase and solid phase with considerably longer retention of the liquid phase ${ }^{(79,80)}$. This difference is the result of the retrograde transport of fluid from the proximal colon to the caecum when hard faeces are produced ${ }^{(81)}$. In pigs, caecal residence time of digesta accounted for 3.6 to $13 \cdot 1 \%^{(75,82)}, 5 \cdot 6$ to $12 \cdot 2 \%^{(83)}$ and $6 \cdot 4$ to $8 \cdot 5 \%^{(84)}$ of the total large intestinal transit time. In the latter study, colonic transit time was affected by dietary treatment, with pigs fed a wheat flour-based bread showing a longer mean colonic transit time $(56.0 \mathrm{~h})$ than pigs fed one of the three other bread types (23.5 to $28.9 \mathrm{~h}$ ). This suggests that pigs adjust colonic transit rather than caecal residence of digesta, as observed in rats. As in humans, porcine total large intestinal transit time may be considerable with transit times up to $73 \cdot 1 \mathrm{~h}^{(85)}$. The rate of passage through the large intestine may be very fast in pigs as compared to the other animal species and was observed to be $21.3 \mathrm{~cm} / \mathrm{h}$ in pigs fed a corn starch diet and $17.8 \mathrm{~cm} / \mathrm{h}$ in pigs fed a raw potato starch diet ${ }^{(86)}$. This rapid transit may also be due to the high feeding level of the pigs. The pigs fed the raw potato starch diet also showed an increased length of the large intestine $(410 \mathrm{~cm} \mathrm{vs.} 340 \mathrm{~cm})$ and prolonged transit time through the colon (23 vs. $16 \mathrm{~h})^{(86)}$. In dogs, transit time of digesta through the large intestine is also highly variable and generally increases with increasing body size ${ }^{(87)}$, although it may vary considerable making prediction of transit time through the large intestine of dogs varying in body weight difficult ${ }^{(88)}$. Dogs with a body weight of $23.9 \mathrm{~kg}$ (Giant Schnauzer) showed an average large intestinal transit time of $39 \cdot 4 \mathrm{~h}^{(87)}$ which is close to the average observed in human subjects ${ }^{(71,72)}$. Based on a length of the large intestine of $79.2 \mathrm{~cm}$ for a $13.8 \mathrm{~kg}$ dog calculated from Snipes and Snipes ${ }^{(62)}$ and a large intestinal transit time of $18.5 \mathrm{~h}$ for a $12.9 \mathrm{~kg} \mathrm{dog}{ }^{(87)}$ the estimated rate of transit is approximately $4.3 \mathrm{~cm} / \mathrm{h}$. Caecal residence time is short in dogs and was found to be $1.0 \%$ for PEG and Cr-EDTA markers and $4.8 \%$ for radiopaque polyethylene markers ${ }^{(75,89)}$. Cats showed considerably longer large intestinal transit times of $26 \cdot 8 \mathrm{~h}^{(90)}$. With a length of $24.3 \mathrm{~cm}$ for the feline large intestine ${ }^{(62)}$, the estimated rate of passage was $0.9 \mathrm{~cm} / \mathrm{h}$. In conclusion, the transit of digesta through the large intestine in terms of duration and rate differs considerably between animal species. Both the transit time and the rate of transit of digesta through the large intestine observed in dogs appears to be comparable to mean values observed in and estimated for human subjects.

Both morphometrically and in terms of transit time, dogs would appear to be closest (of the species studied here) to humans. Limited information is available with regard to similarity in large intestinal microbial activity between both species. Minor differences in total short-chain fatty acid production were found between human and canine faecal inocula when incubated with types of fibre in vitro ${ }^{(91)}$ but it is unknown if the microbial degradation of amino acids is similar between species. Data on differences between apparent ileal and faecal or true amino acid digestibility in dogs are limited to one study ${ }^{(92)}$ where significant differences in apparent faecal digestibility values (faeces-ileal) have been reported for aspartic acid (7.2\%), glycine (6.1\%), methionine $(-3.6 \%)$, proline $(5.2 \%)$, serine $(5.8 \%)$ and threonine (6.8\%). For growing pigs, much more data are available which indicate that there is no apparent pattern in hindgut amino acid catabolism, although several authors have commented on the net synthesis of methionine and lysine in the large intestine ${ }^{(10,54,92,93)}$. The latter makes prediction of the magnitude of the error in apparent faecal digestibility of individual amino acids in humans difficult. Based on the increased $\mathrm{N}$ disappearance with decreasing ileal protein digestibility, it can be expected that the magnitude of the error increases with decreasing protein digestibility.

\section{Conclusion}

Large intestinal $\mathrm{N}$ disappearance due to microbial metabolism of $\mathrm{N}$-containing substrates resulting in $\mathrm{NH}_{3}$ formation and absorption increases with decreasing apparent ileal digestibility of protein for horses, dogs, rats, and pigs. Nitrogen disappearance from the large intestine of chickens and blue foxes appears to be minimal although for the latter species limited data are available. Based on morphometric and transit time data, it can be expected that the $\mathrm{N}$ disappearance from the large intestine of adult humans is similar to that of adult 
Table 2. Mean large intestinal (LI) transit times for several non-ruminant animal species

\begin{tabular}{|c|c|c|c|c|c|c|c|}
\hline \multirow[b]{2}{*}{ Reference } & \multirow[b]{2}{*}{ Species } & \multirow[b]{2}{*}{$n$} & \multirow[b]{2}{*}{ BW $(\mathrm{kg})$} & \multirow[b]{2}{*}{ Marker } & \multicolumn{3}{|c|}{ Mean transit time $(\mathrm{h})$} \\
\hline & & & & & Caecal & Colonic & Total LI \\
\hline Madsen ${ }^{(70)}$ & Human & 33 & n.i. & ${ }^{111} \mathrm{n}$-labelled plastic $(2-3 \mathrm{~mm})$ & & & $9 \cdot 0-46 \cdot 0$ \\
\hline Graff et al. ${ }^{(71)}$ & Human & 18 & n.i. & ${ }^{111}$ In-DTPA & & & $21 \cdot 0-76 \cdot 0$ \\
\hline Madsen and Graff ${ }^{(72)}$ & Human, young & 16 & n.i. & ${ }^{111}$ In-DTPA & & & $14 \cdot 0-75 \cdot 0$ \\
\hline Thompson and Hollis ${ }^{(78)}$, Warner ${ }^{(75)}$ & Rat & 6 & 0.220 & ${ }^{106} \mathrm{Ru}$ & 3.8 & $5 \cdot 2$ & 9.0 \\
\hline $\operatorname{Varga}^{(74)}$, Warner $^{(75)}$ & Rat & n.i & n.i. & n.i. & $2 \cdot 2-11 \cdot 0$ & $15 \cdot 9-26 \cdot 4$ & $18 \cdot 1-37 \cdot 4$ \\
\hline Goodlad and Mathers ${ }^{(94)}$ & Rat & 6 & $0.217^{*}$ & $\mathrm{Cr}_{2} \mathrm{O}_{3}$ & $9 \cdot 4-21 \cdot 1$ & & \\
\hline Goodlad and Mathers ${ }^{(76)}$ & Rat & 6 & $0 \cdot 150^{*}$ & $\mathrm{Cr}_{2} \mathrm{O}_{3}$ & $11 \cdot 3-36 \cdot 2$ & $4 \cdot 3-7 \cdot 0$ & $16 \cdot 3-43 \cdot 2$ \\
\hline Mathers et al. ${ }^{(77)}$ & Rat & 5 & $0.100^{*}$ & $\mathrm{Cr}_{2} \mathrm{O}_{3}$ & $8 \cdot 2-32 \cdot 4$ & $10 \cdot 1-11 \cdot 6$ & $19 \cdot 8-42 \cdot 8$ \\
\hline Gidenne and Jehl ${ }^{(80)}$ & Rabbit & 5 & $0.51^{*}$ & $\begin{array}{l}\text { Ce-labelled fibre } \\
\text { Cr-EDTA }\end{array}$ & & & $\begin{array}{l}6 \cdot 9-7 \cdot 3 \\
27 \cdot 2-34 \cdot 3\end{array}$ \\
\hline Gidenne and Bellier ${ }^{(79)}$ & Rabbit & $4-5$ & $1 \cdot 2-1 \cdot 5$ & $\begin{array}{l}\text { Ce-labelled fibre } \\
\text { Cr-EDTA }\end{array}$ & & & $\begin{array}{l}7 \cdot 8-14 \cdot 7 \\
38 \cdot 1-42 \cdot 4\end{array}$ \\
\hline Moore-Colyer et al. ${ }^{(95)}$ & Horse & 3 & 250 & Nylon bag & & & $51.9-62.0 \dagger$ \\
\hline Keys Jr and DeBarthe ${ }^{(96)}$ & Pig & 4 & n.i. & Sudan III dye & & & $30 \cdot 0-37.5 \ddagger$ \\
\hline Clemens et al. ${ }^{(82)}$, Warner ${ }^{(75)}$ & Pig & 4 & 176 & $\begin{array}{l}\text { PEG and Cr-EDTA } \\
\text { Radiopaque polyethylene }(2,10,20 \mathrm{~mm})\end{array}$ & $\begin{array}{l}1 \cdot 2 \\
4 \cdot 3\end{array}$ & $\begin{array}{l}32 \cdot 2 \\
28 \cdot 6\end{array}$ & $\begin{array}{l}33.4 \\
32 \cdot 9\end{array}$ \\
\hline Vervaeke et al. ${ }^{(97)}$ & Pig & 4 & $30^{*}$ & 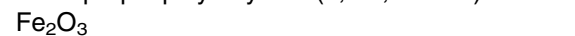 & & & $19 \cdot 9-43.5$ \\
\hline Morales et al. ${ }^{(83)}$ & $\begin{array}{l}\text { Pig, Landrace } \\
\text { Pig, Iberian }\end{array}$ & $\begin{array}{l}6 \\
6\end{array}$ & $\begin{array}{l}107 \\
107\end{array}$ & $\begin{array}{l}\mathrm{Cr}_{2} \mathrm{O}_{3} \\
\mathrm{Cr}_{2} \mathrm{O}_{3}\end{array}$ & $\begin{array}{l}1.3-1.6 \\
0.7-0.8\end{array}$ & $\begin{array}{l}16 \cdot 9-21 \cdot 9 \\
4.8-11 \cdot 2\end{array}$ & $\begin{array}{l}18 \cdot 5-23 \cdot 2 \\
5 \cdot 4-12 \cdot 1\end{array}$ \\
\hline Martinez-Puig et al. ${ }^{(86)}$ & Pig & 6 & $27 \cdot 4^{*}$ & $\mathrm{Cr}_{2} \mathrm{O}_{3}$ & & $16 \cdot 0-23 \cdot 0$ & \\
\hline van Leeuwen et al. ${ }^{(85)}$ & Pig & 6 & $49-119$ & $\mathrm{BaSO}_{4}$ & & & $49 \cdot 2-73 \cdot 1$ \\
\hline Partanen et al. ${ }^{(98)}$ & Pig & 6 & $34^{*}$ & $\begin{array}{l}\text { Co-EDTA } \\
\text { Yb-labelled fibre }\end{array}$ & & & $\begin{array}{l}27 \cdot 6-34 \cdot 1 \\
26 \cdot 9-33 \cdot 6\end{array}$ \\
\hline Wilfart et al. ${ }^{(99)}$ & Pig & 6 & $33^{*}$ & $\begin{array}{l}\mathrm{Yb}_{2} \mathrm{O}_{3} \\
\mathrm{Cr}-\mathrm{EDTA}\end{array}$ & & & $\begin{array}{l}35 \cdot 6-44 \cdot 4 \\
24 \cdot 9-41 \cdot 3\end{array}$ \\
\hline Le Gall et al. ${ }^{(84)}$ & Pig & 5 & $64 \cdot 9^{*}$ & $\mathrm{Cr}_{2} \mathrm{O}_{3}$ & $1 \cdot 6-4.2$ & $23.5-56.0$ & $25 \cdot 1-60 \cdot 2 \S$ \\
\hline Banta et al. ${ }^{(89)}$, Warner $^{(75)}$ & Dogs & 3 & n.i. & PEG and Cr-EDTA & 0.9 & $17 \cdot 1$ & $18 \cdot 0$ \\
\hline Bruce et al. ${ }^{(100)}$ & Dogs & 10 & 20.2 & Radiopaque polyethylene $(2,10,20 \mathrm{~mm})$ & 0.2 & 11.7 & $\begin{array}{l}11 \cdot 9 \\
7 \cdot 1-42.9\end{array}$ \\
\hline Hernot et al. ${ }^{(87)}$ & Dogs & 6 & $3 \cdot 8-51 \cdot 5$ & Sulfasalazine-sulfapyridine and plastic $(2 \cdot 2 \mathrm{~mm})$ & & & $9 \cdot 1-39 \cdot 4 \pm$ \\
\hline Boillat et al. ${ }^{(88)}$ & Dogs & 31 & $19 \cdot 6-81 \cdot 2$ & Wireless capsule $(13 \times 26 \mathrm{~mm})$ & & & $9.7-46 \cdot 1$ \\
\hline Chandler et al. ${ }^{(90)}$ & Cats & 5 & n.i. & Ba-impregnated polyethylene $(1.5,5 \mathrm{~mm})$ & & & $26 \cdot 8$ \\
\hline
\end{tabular}

Abbreviations: BW, body weight; EDTA, ethylenediaminetetraacetic acid; PEG, polyethylene glycol; DTPA, diethylenetriaminepentaacetic acid.

"Initial body weight.

$\dagger$ Calculated as the difference between mean gastro-caecal and total tract transit times.

¥Calculated as the difference between mean oro-caecal and total tract transit times.

$\S$ Calculated as the sum of mean caecal and mean colonic transit times. 
dogs. For every unit of $\mathrm{N}$ entering the large intestine, $50 \%$ is absorbed indicating a major metabolism of N-containing compounds. As the majority of amino acids in the hindgut are found in microbial bodies, significant microbial metabolism of dietary and endogenous amino acids occurs and determination of amino acid digestibility at a faecal level in humans consuming low quality proteins would likely be highly inaccurate as a determinant of the amino acids absorbed from the intestine.

\section{Acknowledgements}

This research received no specific grant from a funding agency in the public, commercial or not for-profit sectors, and therefore this work is free of any conflicts of interest. All authors contributed fundamentally to the present study. W.H.H. and G.B. contributed to all facets, including data collection, analysis, interpretation, and manuscript preparation. J.v.B. contributed to interpretation and preparation of specific sections.

\section{References}

1. NRC (2006) Nutrient requirements of dogs and cats. Washington, D.C., USA: National Academy Press.

2. Hendriks WH \& Emmens M (1998) Apparent ileal nitrogen and amino acid digestibility of a moist cat food. J Nutr $\mathbf{1 2 8}$, 2801S-2802S.

3. Gibson JA, Sladen GE \& Dawson AM (1976) Protein absorption and ammonia production - the effects of dietary protein and removal of the colon. Br J Nutr 35, 61-65.

4. Rowan AM, Moughan PJ, Wilson MN, et al. (1994) Comparison of the ileal and faecal digestibility of dietary amino acids in adult humans and evaluation of the pig as a model animal for digestion studies in man. BrJ Nutr 71, 29-42.

5. Bos C, Mahe S, Gaudichon C, et al. (1999) Assessment of net postprandial protein utilization of N-15-labelled milk nitrogen in human subjects. Br J Nutr 81, 221-226.

6. Mariotti F, Mahe S, Benamouzig R, et al. (1999) Nutritional value of [N-15]-soy protein isolate assessed from ileal digestibility and postprandial protein utilization in humans. J Nutr 129, 1992-1997.

7. Moughan PJ, Butts CA, van Wijk H, et al. (2005) An acute ileal amino acid digestibility assay is a valid procedure for use in human ileostomates. J Nutr 135, 404-409.

8. Deglaire A, Bos C, Tomé D, et al. (2009) Ileal digestibility of dietary protein in the growing pig and adult human. Br J Nutr 102, 1752-1759.

9. Coles LT, Moughan PJ, Awati A, et al. (2010) Predicted apparent digestion of energy yielding nutrients differs between the upper and lower digestive tracts in rats and humans. J Nutr 140, 469-476.

10. Fuller MF \& Tomé D (2005) In vivo determination of amino acid bioavailability in humans and model animals. $J A O A C$ Int 88, 923-934.

11. Cummings JH (1983) Fermentation in the human large intestine - Evidence and implications for health. Lancet 1, 1206-1209.

12. Fahey GC Jr, Flickinger AE, Grieshop CM, et al. (2004) The role of dietary fibre in companion animal nutrition. In Dietary fibre: bio-active carbohydrates for food and feed, pp. 295-328 [JWvd Kamp, N-G Asp, J Miller Jones and G Schaafsma, editors]. Wageningen, The Netherlands: Wageningen Academic Publishers.

13. Said HM \& Mohammed ZM (2006) Intestinal absorption of water-soluble vitamins: an update. Curr Opin Gastroen 22, 140-146

14. de Graaf AA \& Venema K (2008) Gaining insight into microbial physiology in the large intestine: A special role for stable isotopes. In Advances in Microbial Physiology, pp. $73-168$.

15. DiBaise JK, Zhang H, Crowell MD, et al. (2008) Gut microbiota and its possible relationship with obesity. Mayo Clin Proc 83, 460-469.

16. Mason VC, Just A \& Bech-Andersen S (1976) Bacterial activity in the hind-gut of pigs 2 . Its influence on the apparent digestibility of nitrogen and amino acids. $Z$ Tierphysiol Tierer 36, 310-324

17. Low AG \& Zebrowska T (1980) Digestion in pigs. In Protein metabolism in farm animals, pp. 53-121 [HD Bock, BO Eggum, AG Low, O Simon and T Zebrowska, editors]. Oxford, U.K.: Oxford University Press.

18. Stephen AM \& Cummings JH (1980) The microbial contribution to human faecal mass. J Med Microbiol 13, 45-56.

19. Hatanaka T, Huang W, Nakanishi T, et al. (2002) Transport of D-serine via the amino acid transporter $\operatorname{ATB}(0,+)$ expressed in the colon. Biochem Biophys Res Commun 291, 291-295.

20. Prasad PD, Wang HP, Huang W, et al. (1999) Human LAT1, a subunit of system L amino acid transporter: Molecular cloning and transport function. Biochem Biophys Res Commun 255, 283-288.

21. Fraga S, Pinho MJ \& Soares-da-Silva P (2005) Expression of LAT1 and LAT2 amino acid transporters in human and rat intestinal epithelial cells. Amino Acids 29, 229-233.

22. Woodward AD, Holcombe SJ, Steibel JP, et al. (2010) Cationic and neutral amino acid transporter transcript abundances are differentially expressed in the equine intestinal tract. J Anim Sci 88, 1028-1033.

23. Howard A, Tahir I, Javed S, et al. (2010) Glycine transporter GLYT1 is essential for glycine-mediated protection of human intestinal epithelial cells against oxidative damage. J Physiol 588, 995-1009.

24. Anderson $\mathrm{CMH}$, Howard A, Walters JRF, et al. (2009) Taurine uptake across the human intestinal brush-border membrane is via two transporters: $\mathrm{H}^{+}$-coupled PAT1 (SLC36A1) and $\mathrm{Na}^{+}$- and $\mathrm{Cl}^{-}$dependent TauT (SLC6A6). J Physiol 587, 731-744.

25. Gilbert ER, Wong EA, Vaughan M, et al. (2007) Distribution and abundance of nutrient transporter mRNA in the intestinal tract of the black bear, Ursus americanus. Comp Biochem Physiol B Biochem Mol Biol 146, 35-41.

26. Ugawa S, Sunouchi Y, Ueda T, et al. (2001) Characterization of a mouse colonic system $\mathrm{B} 0+$ amino acid transporter related to amino acid absorption in colon. Am J Physiol Gastrointest Liver Physiol 281, G365-G370.

27. Nakanishi T, Hatanaka T, Huang T, et al. (2001) $\mathrm{Na}^{+}-$and $\mathrm{Cl}^{-}$-coupled active transport of carnitine by the amino acid transporter $\operatorname{ATB}(0,+)$ from mouse colon expressed in HRPE cells and Xenopus oocytes. I Physiol 532, 297-304.

28. Kanai Y \& Hediger MA (2004) The glutamate/neutral amino acid transporter family SLC1: Molecular, physiological and pharmacological aspects. Pflug Arch Eur J Phy 447, 469-479.

29. Avissar NE, Ryan CK, Ganapathy V, et al. (2001) $\mathrm{Na}^{+}-$ dependent neutral amino acid transporter $\operatorname{ATB}(0)$ is a 
rabbit epithelial cell brush-border protein. Am J Physiol Cell $\mathrm{Ph}$ 281, C963-C971.

30. Bröer S (2008) Amino acid transport across mammalian intestinal and renal epithelia. Physiol Rev 88, 249-286.

31. Anderson CMH, Grenade DS, Boll $\mathrm{M}$, et al. (2004) $\mathrm{H}^{+} /$ amino acid transporter 1 (PAT1) is the imino acid carrier: An intestinal nutrient/drug transporter in human and rat. Gastroenterology 127, 1410-1422.

32. Boll M, Foltz MT, Rubio-Aliaga I, et al. (2002) Functional characterization of two novel mammalian electrogenic proton-dependent amino acid cotransporters. J Biol Chem 277, 22966-22973.

33. Takanaga H, Mackenzie B, Suzuki Y, et al. (2005) Identification of mammalian proline transporter SIT1 (SLC6A20) with characteristics of classical system imino. J Biol Chem 280, 8974-8984

34. Shen H, Smith DE \& Brosius FC (2001) Developmental expression of PEPT1 and PEPT2 in rat small intestine, colon, and kidney. Pediatr Res 49, 789-795.

35. Chen H, Wong EA \& Webb KE (1999) Tissue distribution of a peptide transporter mRNA in sheep, dairy cows, pigs, and chickens. J Anim Sci 77, 1277-1283.

36. Adibi SA (2003) Regulation of expression of the intestinal oligopeptide transporter (Pept-1) in health and disease. Am J Physiol Gastrointest Liver Physiol 285, G779-G788.

37. Ziegler TR, Fernandez-Estivariz C, Gu LH, et al. (2002) Distribution of the $\mathrm{H}^{+}$/peptide transporter PepT1 in human intestine: up-regulated expression in the colonic mucosa of patients with short-bowel syndrome. Am J Clin Nutr 75, 922-930

38. Zhang EY, Emerick RM, Pak YA, et al. (2004) Comparison of human and monkey peptide transporters: PEPT1 and PEPT2. Mol Pharmaceutics 1, 201-210.

39. Ford D, Howard A \& Hirst BH (2003) Expression of the peptide transporter hPepT1 in human colon: a potential route for colonic protein nitrogen and drug absorption. Histochem Cell Biol 119, 37-43.

40. Smith EA \& Macfarlane GT (1997) Dissimilatory amino acid metabolism in human colonic bacteria. Anaerobe 3, 327-337.

41. Cotta MA, Whitehead TR \& Zeltwanger RL (2003) Isolation, characterization and comparison of bacteria from swine faeces and manure storage pits. Environ Microbiol 5, 737-745.

42. Blachier F, Mariotti F, Huneau JF, et al. (2007) Effects of amino acid-derived luminal metabolites on the colonic epithelium and physiopathological consequences. Amino Acids 33, 547-562.

43. Smith EA \& MacFarlane GT (1998) Enumeration of amino acid fermenting bacteria in the human large intestine: Effects of $\mathrm{pH}$ and starch on peptide metabolism and dissimilation of amino acids. FEMS Microbiol Ecol 25, 355-368.

44. Hoover WH \& Heitmann RN (1975) Cecal nitrogen metabolism and amino acid absorption in the rabbit. $J$ Nutr 105, 245-252.

45. Slade LM, Bishop R, Morris JG, et al. (1971) Digestion and absorption of $15 \mathrm{~N}$-labelled microbial protein in the large intestine of the horse. $\mathrm{Br}$ Vet $\mathrm{J} \mathbf{1 2 7}$, xi-xiii.

46. Wysocki AA \& Baker JP (1975) Utilization of bacterial protein from the lower gut of the equine. Fourth Equine Nutrition Physiology Symposium, 21.

47. Malbert CH (2005) The ileocolonic sphincter. Neurogastroent Motil 17, S41-S49.

48. Santos AS, Rodrigues MAM, Bessa RJB, et al. (2011) Understanding the equine cecum-colon ecosystem: current knowledge and future perspectives. Animal 5, 48-56.
49. Obst BS \& Diamond JM (1989) Interspecific variation in sugar and amino acid transport by the avian cecum. $J$ Exp Zool 252, 117-126.

50. Planas JM, González E, Ferrer R, et al. (1997) Transport of L-valine by the chicken caecum. Br Poultry Sci $\mathbf{3 8}$, 307-310.

51. Sepúlveda FV \& Smith MW (1979) Different mechanisms for neutral amino acid uptake by new-born pig colon. J Physiol 286, 479-490

52. Darragh AJ, Cranwell PD \& Moughan PJ (1994) Absorption of lysine and methionine from the proximal colon of the piglet. Br J Nutr 71, 739-752.

53. Niiyama M, Deguchi E, Kagota K, et al. (1979) Appearance of $15 \mathrm{~N}$-labelled intestinal microbial amino acids in the venous blood of the pig colon. Am J Vet Res 40, 716-718.

54. Moughan PJ (2003) Amino acid availability: Aspects of chemical analysis and bioassay methodology. Nutr Res Rev 16, 127-141.

55. NRC (2007) Nutrient requirements of horses. Washington, D.C., USA: National Academy Press.

56. Murray SM, Patil AR, Fahey Jr GC, et al. (1997) Raw and rendered animal by-products as ingredients in dog diets. J Anim Sci 75, 2497-2505.

57. Knabe DA, LaRue DC, Gregg EJ, et al. (1989) Apparent digestibility of nitrogen and amino acids in protein feedstuffs by growing pigs. J Anim Sci 67, 441-458.

58. Propst EL, Flickinger AE, Bauer LL, et al. (2003) A doseresponse experiment evaluating the effects of oligofructose and inulin on nutrient digestibility, stool quality, and fecal protein catabolites in healthy adult dogs. J Anim Sci 81, 3057-3066.

59. Stevens EC \& Hume ID (1998) Contributions of microbes in vertebrate gastrointestinal tract to production and conservation of nutrients. Physiol Rev 78, 393-427.

60. Williams BA, Verstegen MWA \& Tamminga S (2001) Fermentation in the large intestine of single-stomached animals and its relationship to animal health. Nutr Res Rev 14, 207-227.

61. Snipes RL \& Kriete A (1991) Quantitative investigation of the area and volume in different compartments of the intestine of 18 mammalian species. Z Saugetierkd 56, 225-244.

62. Snipes RL \& Snipes H (1997) Quantitative investigation of the intestines in eight species of domestic mammals. Z Saugetierkd 62, 359-371.

63. Snipes RL (1997) Intestinal absoprtive surface in mammals of different sizes. Adv Anat Embryol Cel 138, 1-90.

64. McGowan I, Campbell A \& Jewell DP (1994) Intestinal mucosal abnormality associated with human-immunodeficiency-virus infection. Eur J Gastroen Hepat 6, 813-819.

65. Humphrey BD, Huang N \& Klasing KC (2002) Rice expressing lactoferrin and lysozyme has antibiotic-like properties when fed to chicks. J Nutr 132, 1214-1218.

66. Vente-Spreeuwenberg MAM \& Beynen AC (2003) Dietmediated modulation of small intestinal integrity in weaned piglets. In Weaning the pig: Concepts and consequences, pp. 145-198 [JR Pluske, J Le Dividich and MWA Verstegen, editors]. Wageningen, the Netherlands: Wageningen Academic Publishers.

67. Trbojevic-Stankovic JB, Milicevic NM, Milosevic DP, et al. (2010) Morphometric study of healthy jejunal and ileal mucosa in adult and aged subjects. Histol Histopathol 25, $153-158$

68. Chivers DJ \& Hladik CM (1980) Morphology of the gastrointestinal tract in primates: Comparisons with other mammals in relation to diet. J Morphol 166, 337-386. 
69. Stephen AM, Wiggins HS \& Cummings JH (1987) Effect of changing transit time on colonic microbial metabolism in man. Gut 28, 601-609.

70. Madsen JL (1992) Effects of gender, age, and body mass index on gastrointestinal transit times. Dig Dis Sci 37, $1548-1553$

71. Graff J, Brinch K \& Madsen JL (2001) Gastrointestinal mean transit times in young and middle-aged healthy subjects. Clin Physiol 21, 253-259.

72. Madsen JL \& Graff J (2004) Effects of ageing on gastrointestinal motor function. Age Ageing 33, 154-159.

73. Maurer AH \& Parkman HP (2006) Update on gastrointestinal scintigraphy. Semin Nucl Med 36, 110-118.

74. Varga F (1976) Transit time changes with age in the gastrointestinal tract of the rat. Digestion 14, 319-324.

75. Warner ACI (1981) Rate of passage of digesta through the gut of mammals and birds. Nutr Abstr Rev Ser B Livest Feeds Feed 51, 789-819.

76. Goodlad JS \& Mathers JC (1992) Digestion of complex carbohydrates and large bowel fermentation in rats fed on raw and cooked peas (Pisum sativum). Br J Nutr 67, 475-488.

77. Mathers JC, Smith H \& Carter S (1997) Dose-response effects of raw potato starch on small-intestinal escape, large-bowel fermentation and gut transit time in the rat. Br J Nutr 78, 1015-1029.

78. Thompson RC \& Hollis OL (1958) Irradation of the gastrointestinal tract of the rat by ingested ruthenium-106. Am J Physiol 194, 308-312.

79. Gidenne T \& Bellier R (2000) Use of digestible fibre in replacement to available carbohydrates. Effect on digestion, rate of passage and caecal fermentation pattern during the growth of the rabbit. Livest Prod Sci 63, 141-152.

80. Gidenne T \& Jehl N (1996) Replacement of starch by digestible fibre in the feed for the growing rabbit. 1. Consequences for digestibility and rate of passage. Anim Feed Sci Technol 61, 183-192.

81. Björnhag G (1981) The retrograde transport of fluid in the proximal colon of rabbits. Swed J Agric Res 11, 63-69.

82. Clemens ET, Stevens CE \& Southworth M (1975) Sites of organic acid production and pattern of digesta movement in the gastrointestinal tract of swine. J Nutr 105, 759-768.

83. Morales J, Perez JF, Martin-Orue SM, et al. (2002) Large bowel fermentation of maize or sorghum-acorn diets fed as a different source of carbohydrates to Landrace and Iberian pigs. Br J Nutr 88, 489-497.

84. Le Gall M, Serena A, Jørgensen H, et al. (2009) The role of whole-wheat grain and wheat and rye ingredients on the digestion and fermentation processes in the gut a model experiment with pigs. Br J Nutr 102, 1590-1600.

85. van Leeuwen P, van Gelder AH, de Leeuw JA, et al. (2006) An animal model to study digesta passage in different compartments of the gastro-intestinal tract (GIT) as affected by dietary composition. Curr Nutr Food Sci 2, 97-105.

86. Martinez-Puig D, Pérez JF, Castillo M, et al. (2003) Consumption of raw potato starch increases colon length and fecal excretion of purine bases in growing pigs. $J$ Nutr 133, 134-139.

87. Hernot DC, Dumon HJ, Biourge VC, et al. (2006) Evaluation of association between body size and large intestinal transit time in healthy dogs. Am J Vet Res 67, 342-347.

88. Boillat CS, Gaschen FP \& Hosgood GL (2010) Assessment of the relationship between body weight and gastrointestinal transit times measured by use of a wireless motility capsule system in dogs. Am J Vet Res 71, 898-902.

89. Banta CA, Clemens ET, Krinsky MM, et al. (1979) Sites of organic acid production and patterns of digesta movement in the gastrointestinal tract of dogs. J Nutr 109, 1592-1600.

90. Chandler ML, Guilford WG, Lawoko CRO, et al. (1999) Gastric emptying and intestinal transit times of radiopaque markers in cats fed a high-fiber diet with and without low-dose intravenous diazepam. Vet Radiol Ultrasoun 40, 3-8.

91. Sunvold GD, Hussein HS, Fahey Jr GC, et al. (1995) In vitro fermentation of cellulose, beet pulp, citrus pulp, and citrus pectin using fecal inoculum from cats, dogs, horses, humans, and pigs and ruminal fluid from cattle. J Anim Sci 73, 3639-3648.

92. Hendriks WH \& Sritharan K (2002) Apparent ileal and fecal digestibility of dietary protein is different in dogs. $J$ Nutr 132, S1692-S1694.

93. Yin YL, Chen CM, Zhong HY, et al. (1994) Apparent digestibilities of energy, cell wall constituents, crude protein and amino acids of Chinese oil seed meals for growing pigs. Anim Feed Sci Technol 45, 283-298.

94. Goodlad JS \& Mathers JC (1990) Large bowel fermentation in rats given diets containing raw peas (Pisum sativum). Br J Nutr 64, 569-587.

95. Moore-Colyer MJS, Hyslop JJ, Longland AC, et al. (2002) The mobile bag technique as a method for determining the degradation of four botanically diverse fibrous feedstuffs in the small intestine and total digestive tract of ponies. BrJ Nutr 88, 729-740.

96. Keys Jr JE \& DeBarthe JV (1974) Site and extent of carbohydrate, dry matter, energy and protein digestion and the rate of passage of grain diets in swine. J Anim Sci 39, $57-62$.

97. Vervaeke IJ, Dierick NA, Demeyer DI, et al. (1989) Approach to the energetic importance of fibre digestion in pigs. II. An experimental approach to hindgut digestion. Anim Feed Sci Technol 23, 169-194.

98. Partanen K, Jalava T \& Valaja I (2007) Effects of a dietary organic acid mixture and of dietary fibre levels on ileal and faecal nutrient apparent digestibility, bacterial nitrogen flow, microbial metabolite concentrations and rate of passage in the digestive tract of pigs. Animal 1, 389-401.

99. Wilfart A, Montagne L, Simmins H, et al. (2007) Digesta transit in different segments of the gastrointestinal tract of pigs as affected by insoluble fibre supplied by wheat bran. Br J Nutr 98, 54-62.

100. Bruce SJ, Guilford WG, Hedderley DI, et al. (1999) Development of reference intervals for the large intestinal transit of radiopaque markers in dogs. Vet Radiol Ultrasoun 40, $472-476$ 